\title{
Induction of Apoptosis and Growth-Inhibition by Thymoquinone in ACHN and GP-293 Cell Lines in Comparable with Cis-Platinum
}

\author{
Samira Shahraki ${ }^{1}$, Reza Mohebbati', Mohammad Naser Shafei ${ }^{2}$, Mahmoud Mahmoudi $^{3}$, \\ Sara Hosseinian ${ }^{1,2}$, Soghra Parhizgar ${ }^{1}$, Zohreh Naji Ebrahimi Yazd ${ }^{1}$, \\ Nazanin Entezari Heravi', Reza Nejad Shahrokh Abadi' ${ }^{4}$ Abolfazl Khajavirad ${ }^{1,2 *}$
}

\footnotetext{
${ }^{1}$ Department of Physiology, Faculty of Medicine, Mashhad University of Medical Sciences, Mashhad, Iran

${ }^{2}$ Neurogenic Inflammation Research Center, Mashhad University of Medical Sciences, Mashhad, Iran

${ }^{3}$ Bu-Ali Research Institute, Immunology Research Center, Faculty of Medicine, Mashhad University of Medical

Sciences, Mashhad, Iran

${ }^{4}$ Faculty of Medicine, Mashhad University of Medical Sciences, Mashhad, Iran
}

\section{Key Words}

Thymoquinone, GP-293 cell line, ACHN cell line, Cis-platinum, cytotoxicity, apoptosis

\begin{abstract}
Objective: In the current work, we investigated the cytotoxic and apoptotic effects of Thymoquinone (TQ), an active compound of Nigella sativa (N. sativa) and Cis-platinum, on normal renal epithelial (GP-293) and human renal adenocarcinoma cell lines (ACHN).

Methods: GP-293 and ACHN cell lines were cultured in Dulbecco's modified Eagle's medium (DMEM) with $10 \%$ Fetal bovine serum (FBS) and 1\% penicillin plus streptomycin antibiotic. The MTT assay was used for cellular viability assessment. Viability of cells was observed using inverted light microscope 24,48 and $72 \mathrm{~h}$ after exposure of the cells to various concentrations of TQ $(1,2.5$, 5, 10, 50 and $100 \mu \mathrm{g} / \mathrm{ml})$ and Cis-platinum $(0.5,1,1.5,2$, 3,6 and $12.5 \mu \mathrm{g} / \mathrm{ml}$ ). Moreover, apoptosis was analyzed with a flow-cytometry method. The untreated cells were
\end{abstract}

Received: Mar 03, 2019 Reviewed: Apr 22, 2019 Accepted: Sep 03, 2019

(c) This is an Open-Access article distributed under the terms of the Creative Common Attribution Non-Commercial License (http://creativecommons.org/licenses/by-nc/4.0/) which permits unrestricted noncommercial use, distribution, and reproduction in any medium, provided the original work is properly cited.

(2) This paper meets the requirements of KS X ISO 9706, ISO 9706-1994 and ANSI/NISO Z39.48-1992 (Permanence of Paper). considered as control group.

Results: Morphological changes such as reduced cell number and increased intercellular distance and reduced cell viability in ACHN and GP-293cell lines were observed in both TQ and Cis- platinum groups; however, Cis-platinum had greater effect on ACHN cell line than GP-293 cell line. In addition, GP-293 cell line was more sensitive to TQ compared to ACHN cell line. Furthermore, TQ and Cis-platinum had apoptotic effects on both ACHN and GP-293 cell lines.

Conclusion: Our findings demonstrated that TQ and Cis-platinum had cytotoxic and apoptotic effects on both cell lines, However, GP-293 cell line was more sensitive to TQ. Additionally, Cis-platinum was more effective on ACHN cell line than on GP-293 cell line.

\section{Introduction}

Renal cell carcinoma (RCC) is a well-known tumor of the kidney with a lack of early warning sign, resistance to chemotherapy and diverse clinical manifestations. There is evidence that growth of the RCC is inhibited by immunotherapy [1]. The RCC genetically leads to 
changes in the gene controlling cellular oxygen sensing and resistance of chromatin states [2]. The incidence of the RCC in men is twice that in women. The most important treatment for this tumor is surgery [3]. Several risk factors are involved in the RCC including obesity, smoking, Western- style diet and gene polymorphisms of antioxidant enzymes [4]. Cis-Platinum is an anti-tumor drug successfully used in clinics as a cancer chemotherapy agent. However, enormous side effects of Cis-Platinum especially nephrotoxicity, limit its therapeutic usefulness [5].

Nigella Sativa (N. sativa), also named black cumin, is a herbal plant from Ranunculaceae family [6]. The N. sativa as traditional and classic medicine is used for treatment and improvement of ample diseases such as asthma [7], renal nephrosis [8], diabetes [9] and some cancers [10]. The seeds of the N. sativa have a low degree of toxicity and contain several components including alkaloids, proteins, and saponin [6]. Thymoquinone (TQ) is the active biological component of the N. sativa, and that its therapeutic effects are evaluated in several studies [11]. The pharmacological properties of the N. sativa and TQ are anti-inflammatory, antioxidant [12], antimicrobial [13] and antineoplastic [14] activities. In several studies, apoptotic effects of TQ were investigated on different cancerous cells such as larynx epidermoid carcinoma (HEp-2), lung carcinoma (A549) and colon adenocarcinoma (HT-29) [15]. In a study, TQ induced apoptosis of canine osteosarcoma cells (COS31) after treatment, reduced the number of COS31 cells at S phase and boosted cells at G1 phase, demonstrating arrest of cell cycle at G1 phase. According to these results, TQ kills cancer cells by a mechanism involving cell cycle arrest and apoptosis. The results of the study showed that healthy cells are relatively resistant to TQ effect [16].

In this study, we investigated cytotoxic and apoptotic effects of TQ as an active compound of N. sativa and Cis-platinum on normal renal epithelial (GP-293) and human renal adenocarcinoma (ACHN) cell lines.

\section{Material and methods}

\subsection{Materials and cell lines}

Fetal bovine serum (FBS) and Dulbecco's modified Eagle's medium (DMEM) were purchased from Gibco (Grand Island, USA). TQ, Cis-platinum and 3-(4, 5-dimethylthiazol-2-yl)-2, 5- diphenyl tetrazolium (MTT) were purchased from Sigma (St Louis, MO, USA). The Annexin V and propidium iodine (PI) kits were supplied by Biovision (USA).

The GP-293 and ACHN cell lines were obtained from the Pasteur Institute (Tehran, Iran) and kept in an incubator containing $5 \% \mathrm{CO} 2$ at $37^{\circ} \mathrm{C}$. The cell lines were cultured in DMEM with $10 \%$ FBS and $1 \%$ penicillin plus streptomycin antibiotic.

\subsection{Cell viability}

The MTT assay was used for cellular viability assessment [17]. The MTT test as a colorimetric method is based on the breakdown and reduction of yellow tetrazolium crystals. After performing the trypan blue test and making a count of live cells, 5000 ACHN cells and 10000 GP- 293 cells were seeded in each well of 96-well plates and allowed to grow for $24 \mathrm{~h}$, where upon the superficial medium of the wells were removed. Each cell line was incubated for 24, 48, and $72 \mathrm{~h}$ with different concentrations of Cis-platinum $(0.5,1$, $1.5,2,3,6$ and $12.5 \mu \mathrm{g} / \mathrm{ml})$ and TQ $(1,2.5,5,10,50$ and $100 \mu \mathrm{g} / \mathrm{ml}$ ) [18]. Each concentration for ACHN and GP-293 cell lines was tested in three replicates. After these intervals, MTT solvent was added to each of the wells. After 4 $\mathrm{h}$ incubation, the medium was removed and then $200 \mathrm{~mL}$ of dimethyl sulfoxide (DMSO) was added to each of the wells. Ultimately, the absorption of each well liquid was measured at $570 \mathrm{~nm}$ (620 $\mathrm{nm}$ as a reference) with an ELISA reader instrument.

\subsection{Morphological studies}

At 24, 48 and $72 \mathrm{~h}$ after the exposure of the cells to various concentrations of TQ and Cis- platinum, the cells in the plates were observed with an inverted light microscope. The untreated cells served as the control group.

\subsubsection{Apoptosis and necrosis quantification}

The Biovision kit was used for measurement of cell apoptosis in GP-293 and ACHN cell lines, [17]. This kit includes Annexin V and PI. Both the cell lines were exposed to TQ and Cis- platinum $24 \mathrm{~h}$ after seeding for $48 \mathrm{~h}$. Afterwards, the cells were collected, and after adding $500 \mathrm{~mL}$ of binding buffer, they were incubated for $5 \mathrm{~min}$ in darkness at room temperature. Next, $5 \mathrm{~mL}$ of Annexin V and $5 \mathrm{~mL}$ of PI were added to the cells and they were incubated for $10 \mathrm{~min}$ under the same conditions. Finally, the samples were analyzed with a flowcytometry instrument. Cells with apoptosis and necrosis were placed in separate flowcytometry plots, and various cell groups were separated.

\subsubsection{Statistical analysis}

The data were presented as mean \pm SEM. One way ANOVA with post-hoc Tukey's test was used for statistical analysis. $\mathrm{P}<0.05$ was considered as statistically significant.

\section{Results}

\subsection{Cell morphology}

Control of GP-293 and ACHN cells in the culture attached to the well bottom, have spindle- shape, fibroblast-like appearance and uniform distribution.

In GP-293 cells $24 \mathrm{~h}$ after treatment with various doses of TQ $(0-100 \mu \mathrm{g} / \mathrm{mL})$, morphological changes such as reduced cell number, increased intercellular distance, and uon-uniform distribution of the cells from the $5 \mu \mathrm{g} /$ $\mathrm{mL}$ concentration were shown (Fig. 1). After 48 and $72 \mathrm{~h}$, these changes were time and dose-dependent (Fig. 2-3). In ACHN cell lines, $24 \mathrm{~h}$ after exposure to TQ, morphological changes such as decreased number of living cells, rounding, and granulation were observed at the $10 \mu \mathrm{g} / \mathrm{mL}$ concentration, and morphological changes were seen with higher severity in dose and time-dependent (Fig. 1-3).

In GP-293 cell line, morphological study of the cells after $24 \mathrm{~h}$ of exposure to Cis-platinum $(0-12.5 \mu \mathrm{g} / \mathrm{mL})$ showed that cells treated at the $3 \mu \mathrm{g} / \mathrm{mL}$ concentration were seen 
in multiple colonies all around the well. Furthermore, many cells became round and granulated (Fig. 1). After 48 and $72 \mathrm{~h}$, these changes became dose and time-dependent (Fig. 2-3). In ACHN cell lines, after $24 \mathrm{~h}$ of exposure to Cis-platinum showed that cells treated at the $1.5 \mu \mathrm{g} /$ $\mathrm{mL}$ concentration covered lower levels than the control groups. Moreover, the cells were observed to have a homogenous distribution and be in multiple colonies all around the well (Fig. 1). By increasing time and dosage, morphological changes occurred in low doses and began with greater intensity (Fig. 2-3).

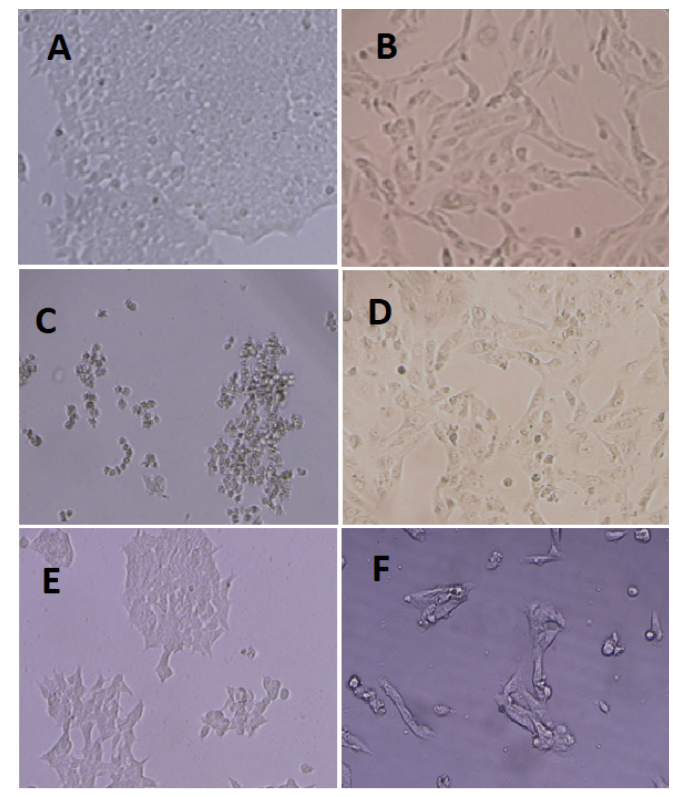

Figure 1 Morphological changes of GP-293 and ACHN cell line after $24 \mathrm{~h} \mathrm{~h}$ treated with $10 \mu \mathrm{g} / \mathrm{mL}$ thymoquinone (TQ) and $3 \mu \mathrm{g} /$ mL Cis-platinum: control GP-293 cells (A), control ACHN cells (B), GP-293 cells treated with TQ (C), ACHN cells treated with TQ (D), GP-293 cells treated with Cis-platinum (E), ACHN cells treated with Cis-platinum (F).

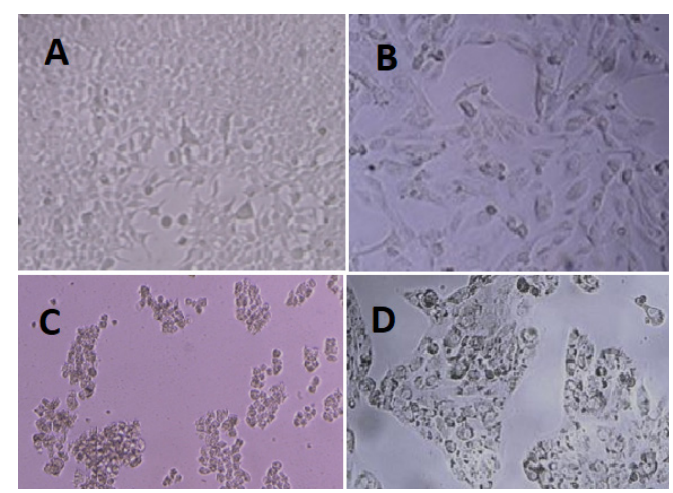

Figure 2 Morphological changes of GP-293 and ACHN cell line after $48 \mathrm{~h}$ h treated with $10 \mu \mathrm{g} / \mathrm{mL}$ thymoquinone (TQ) and $3 \mu \mathrm{g}$ / mL Cis-platinum: control GP-293 cells (A), control ACHN cells (B), GP-293 cells treated with TQ (C), ACHN cells treated with TQ (D), GP-293 cells treated with Cis-platinum (E), ACHN cells treated with Cis-platinum $(\mathrm{F})$.

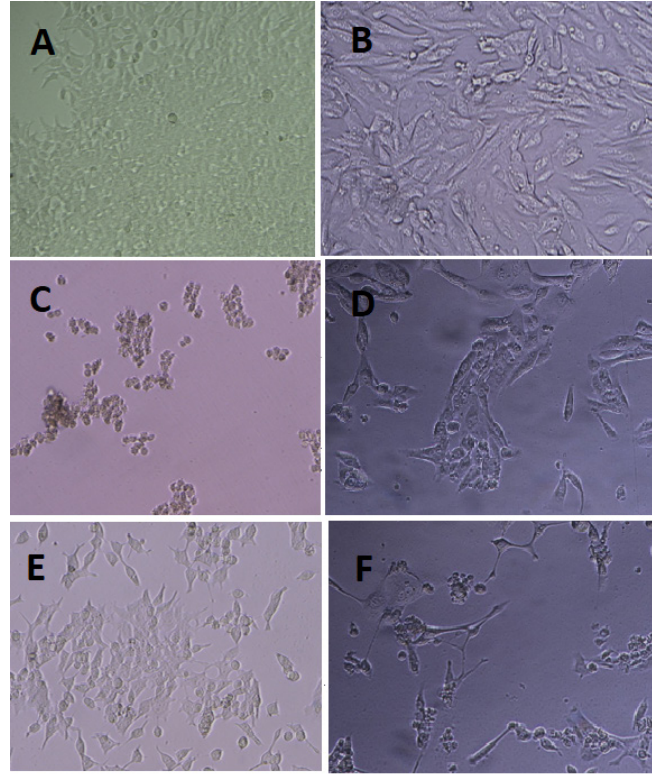

Figure 3 Morphological changes of GP-293 and ACHN cell line after $72 \mathrm{~h}$ h treated with $10 \mu \mathrm{g} / \mathrm{mL}$ thymoquinone (TQ) and $3 \mu \mathrm{g} /$ mL Cis-platinum: control GP-293 cells (A), control ACHN cells (B), GP-293 cells treated with TQ (C), ACHN cells treated with TQ (D), GP-293 cells treated with Cis-platinum (E), ACHN cells treated with Cis-platinum (F).

\subsection{Evaluation of cytotoxicity}

The viability of cell was measured by MTT assay. Fig. 4 shows GP-293 and ACHN cell viability results for TQ concentrations after 24, 48 and $72 \mathrm{~h}$. In GP-293 cells, cell viability was significant during all of the time periods of exposures to TQ from $5 \mu \mathrm{g} / \mathrm{mL}$ concentration in comparison to the control wells. In ACHN cell viability, $24 \mathrm{~h}$ after exposure to different concentrations of TQ, cell viability decreased at the $1 \mu \mathrm{g} / \mathrm{mL}$ concentration compared to the control, but this reduction was significant at the $20 \mu \mathrm{g} / \mathrm{mL}$ concentration. After $48 \mathrm{~h}$, this reduction was meaningful at the $20 \mu \mathrm{g}$ $/ \mathrm{mL}$ concentration. Moreover, significant reduction in cell viability was observed at the $10 \mu \mathrm{g} / \mathrm{mL}$ concentration after $72 \mathrm{~h}(\mathrm{P}<0.001)$, compared to the control group.

In Fig. 5, the effect of different concentrations of Cis-platinum is shown on the MTT test in GP- 293 and ACHN cell lines. In GP-293 cells, after $24 \mathrm{~h}$ of exposure to Cis-platinum, decreased cell viability was recorded at the $1 \mu \mathrm{g} / \mathrm{mL}$ concentration compared to the control wells; however, the reduction was significant at the $6 \mu \mathrm{g} / \mathrm{mL}$ concentration. After $48 \mathrm{~h}$, this reduction was meaningful at the $0.5 \mu \mathrm{g} / \mathrm{mL}$ concentration. As shown, after $72 \mathrm{~h}$ of exposure to Cis-platinum, the cell viability significantly decreased at the $1 \mu \mathrm{g} /$ $\mathrm{mL}$ concentration compared to the control group. In ACHN cells, decreased cell viability was recorded at the $0.5 \mu \mathrm{g} / \mathrm{mL}$ concentration $24 \mathrm{~h}$ after exposure to different concentrations of Cis-platinum as compared to the controls; however, this reduction was significant at the $2 \mu \mathrm{g} / \mathrm{mL}$ concentration. After 48 and $72 \mathrm{~h}$, a meaningful reduction in cell viability was demonstrated at the $0.5 \mu \mathrm{g} / \mathrm{mL}$ concentration in comparison to the controls $(\mathrm{P}<0.01$ to $\mathrm{P}<0.001)$. 

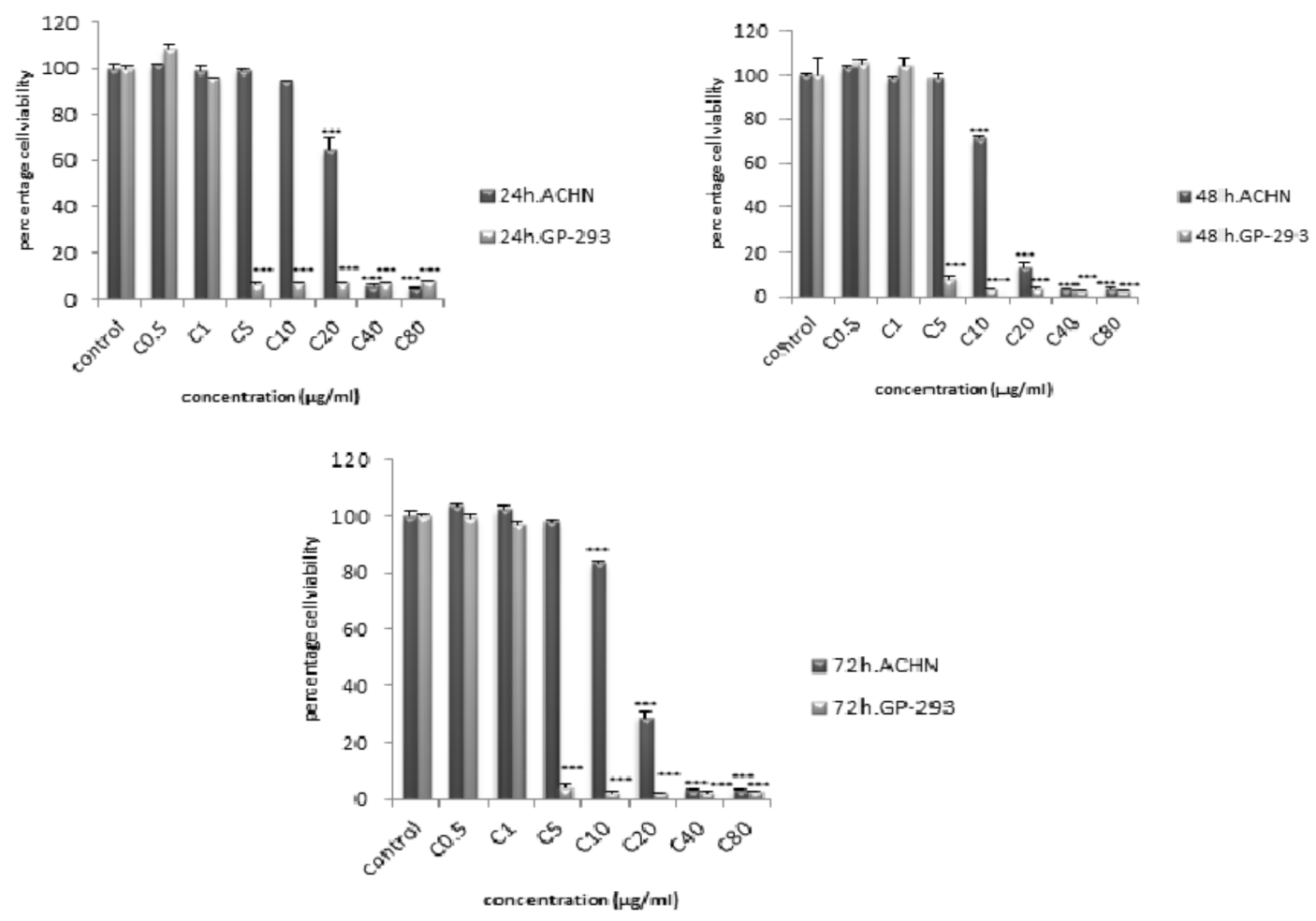

Figure 4 Growth inhibition of GP-293 cell and ACHN cell with different TQ concentrations (C 0.5, C1, C5, C10, C20, C40, C80) after 24, 48 and $72 \mathrm{~h}$. Results are mean $\pm \operatorname{SEM}(\mathrm{n}=3) .{ }^{*} \mathrm{P}<0.05,{ }^{* *} \mathrm{P}<0.01$ and ${ }^{* * *} \mathrm{P}<0.001$ compared to control.
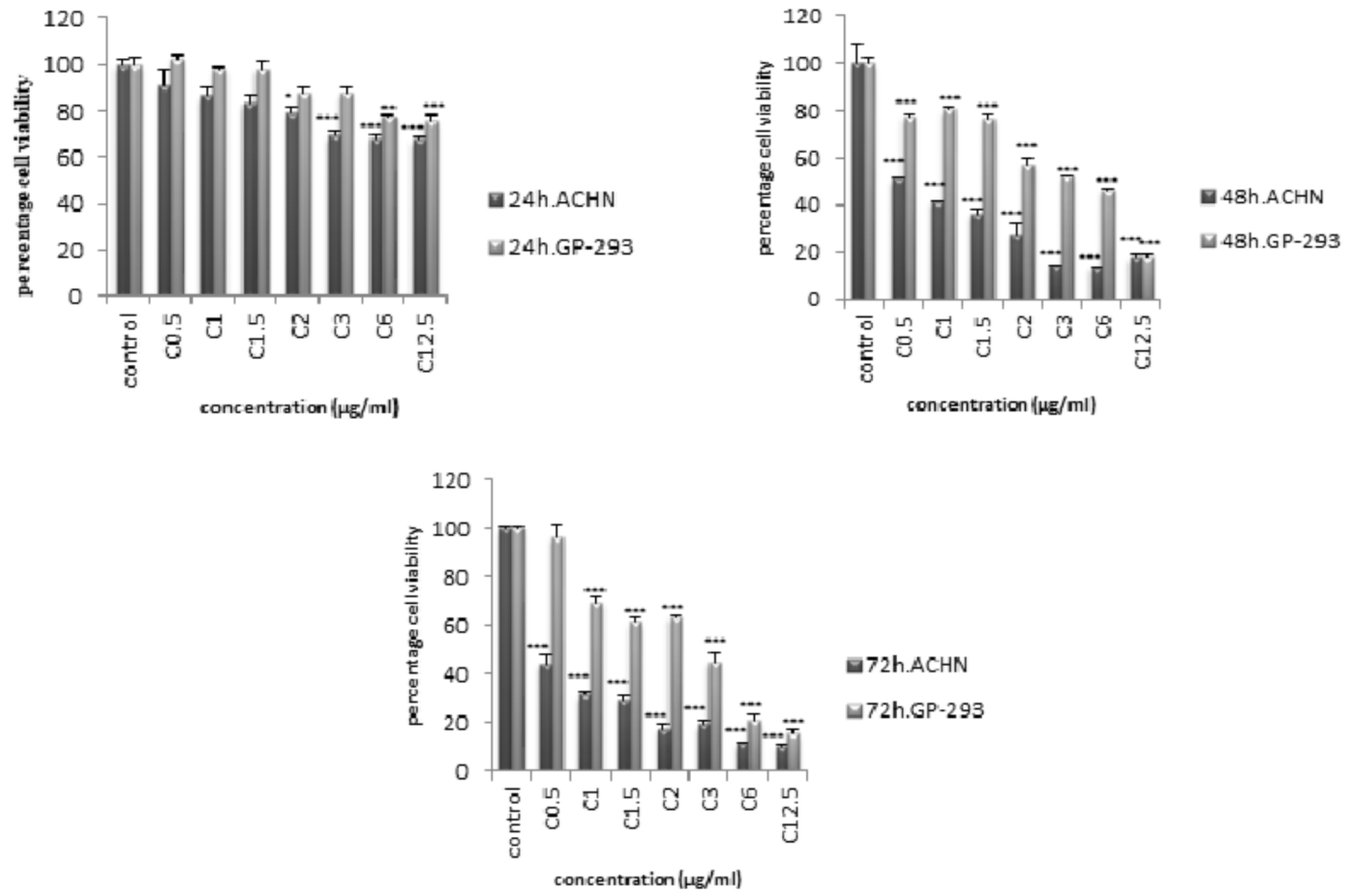

Figure 5 Growth inhibition of GP-293 cell and ACHN cell with different Cis-platinum concentrations (C 0.5, C1, C1.5, C2, C3, C6, C12.5) after 24, 48 and $72 \mathrm{~h}$. Results are mean $\pm \mathrm{SEM}(\mathrm{n}=3) .{ }^{*} \mathrm{P}<0.05,{ }^{* *} \mathrm{P}<0.01$ and ${ }^{* * *} \mathrm{P}<0.001$ compared to control. 


\subsection{Assessment of apoptosis}

In Figure 6, the effect of various TQ concentrations is depicted on induction of apoptosis in GP- 293 and ACHN cell lines. After $48 \mathrm{~h}$, different TQ concentrations in GP-293 cells at the $1 \mu \mathrm{g} / \mathrm{mL}$ concentration induced apoptosis, but this increase was not significant in comparison to the control. In ACHN cell lines, after $48 \mathrm{~h}$ of exposure to TQ, the rate of apoptosis increased at $0.5 \mu \mathrm{g} / \mathrm{mL}$ concentration, but was statically significant only at the $20 \mu \mathrm{g} / \mathrm{mL}$ concentration.

The effect of Cis-platinum on the cell apoptosis percentage in GP-293 and ACHN cells after $48 \mathrm{~h}$ is shown in Fig. 6. It was indicated that at the $0.5 \mu \mathrm{g} / \mathrm{mL}$ concentration and higher, Cis-platinum induced apoptosis in ACHN cells. However, the increased apoptosis rate was significant only at the $1.5 \mu \mathrm{g} / \mathrm{mL}$ concentration. In GP-293 cell lines, after $48 \mathrm{~h}$ of exposure to Cis-platinum, the apoptosis rate increased at the $0.5 \mu \mathrm{g} / \mathrm{mL}$ concentration, but this increase was not significant than apoptosis percentage of control wells $(\mathrm{P}<0.01$ to $\mathrm{P}<0.001)$.
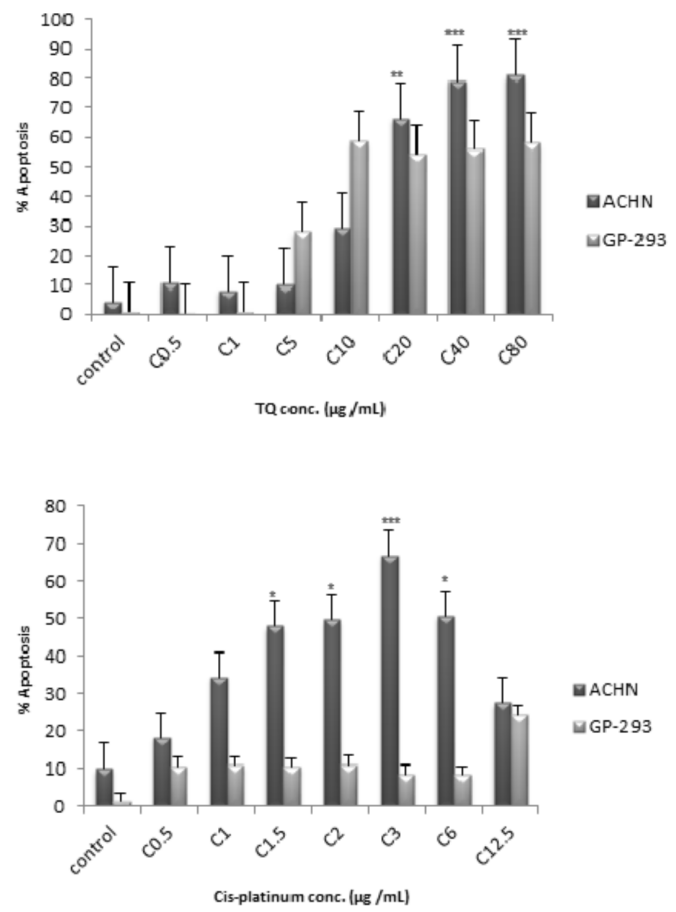

Figure 6 Apoptotic effects of TQ (C 0.5, C1, C5, C10, C20, C40, C80)and Cis-platinum (C 0.5, C1, C1.5, C2, C3, C6, C12.5) in GP293 and ACHN cell after $48 \mathrm{~h}$. Results are mean $\pm \operatorname{SEM}(\mathrm{n}=3) .{ }^{* * *} \mathrm{P}$ $<0.001$ compared to control

\section{Discussion}

We previously reported the the effects of $\mathrm{N}$. sativa total extract and n-hexane, ethyl acetate (EtOAc) and Aqueous fractions of $\mathrm{N}$. sativa on the cells morphology, viability and apoptosis in ACHN and GP-293 cell lines. Also, in the current work, the effect of the TQ and Cis-platinum were evaluated on ACHN and GP-293 cell lines. The results indicated that the cytotoxic and apoptotic effect of the TQ was higher on the GP-293 cell lines than on the ACHN cell lines, but the effect of Cis-platinum was greater on the ACHN cell lines.

The RCC is the sixth significant reason for cancer death, and its annual incidence rate is about $2 \%$. Several experiments including those using medicinal plants were performed for treatment of this cancer [19]. Moreover, There is an increasing interest in the use of traditional medicine in cancer treatment [18]. Anti-cancer properties of N. sativa especially those of TQ, in renal carcinoma as well as in breast, hepatic, skin and cervical cancer were shown in previous studies [20]. However, the molecular mechanisms of the anti-cancer effect of TQ are still unknown [21]. Medicinal plants are a valuable resource for finding new drugs [22]. In the current work, the effects of the TQ and Cis-platinum were evaluated on two renal cell lines (ACHN and GP-293).

The morphological changes were induced by TQ on ACHN and GP-293 cell lines in a dose and time-dependent manner at low concentrations. These changes were higher in GP-293 cell lines than in ACHN cell lines. The effect of TQ observed in this study is consistent with other studies indicating the morphological effect of TQ on three cancer cell lines, i.e. Hela (human cervical carcinoma) [23], M059K and M059J (human glioblastoma) ]24[. Recently, Gamarra-Luques et al. showed that Cis-platinum induced morphologic changes in IGROV-1, A2780 and OV2008 (human ovarian carcinoma cell lines) ]25[. The findings also revealed that Cis-platinum induced morphological changes in both the cell lines, but these changes were stronger in ACHN cell lines than in GP-293 cell lines.

Recent studies showed the anticancer effects of N. sativa on blood, breast, colon, pancreas, liver, lung, skin, kidneys and neck due to TQ [20]. In this study, MTT test showed that TQ had a toxic effect on ACHN and GP-293 cell lines, and that it had higher inhibiting effect on GP-293 cell growth, as compared to ACHN cell line growth. These findings are in line with previous studies, confirming that TQ was able to inhibit cell proliferation in NCI-H460, NCI-H461(lung cancer cell line) ]26[, MCF7/DOX (Doxorubicin-resistant human breast adenocarcinoma) ]27[, BG-1 (human ovarian adenocarcinoma) and COS31 (canine osteosarcoma) [28]. In addition, in this study, TQ was observed to have beneficial effect on renal cancer cell lines; however, TQ effect on renal normal cell lines was a side effect of this agent that may limit the use of this agent. Moreover, in our study, results revealed that Cis-platinum inhibited proliferation of ACHN and GP-293 cell lines, and ACHN cell lines displayed increased sensitivity towards Cis-platinum compared to GP-293 cells lines. These findings are in line with other studies confirming that Cis- platinum decreased cell viability of Hela, SiHa (cervical cancer cell line) ]29[, NT2 and S2 NCCIT (human testicular cancer cell line) [30] and BEL-7404 (human hepatoma cell line) [31].

Based on the results of the present study, TQ induced apoptosis in both the cell lines; however, TQ had higher ability in inducing apoptosis in ACHN cell line compared to GP-293 cell lines. Previous studies also demonstrated that TQ induced apoptosis in various cancer cell types 
such as HL-60 (myeloblastic leukemia) ]32[ and as well as NCI-H460 and NCI-H146 (lung cancer cell line) ]26[. These studies indicated differences in the effect of TQ on apoptosis induction in various cell lines. Therefore, we expect TQ induce apoptosis in cancer cell line by causing G1 and G2/M arrest[33], increased reactive oxygen species (ROS) generation and c-Jun N-terminal kinase (JNK) activation[34].

In this study, Cis-platinum had a selective effect on apoptosis induction in ACHN cell lines compared to GP-293 cell lines. Moreover, Cis-platinum increased the percentage of apoptosis in ACHN cell lines at lower concentrations whereas reduced it at higher concentrations. This showed the shift in the Cis-platinum mechanism from apoptosis to necrosis. These results are consistent with the prev[34]ious studies [17] indicating that Cis-platinum, similar to ethylacetate fractions of N. sativa had dual effects on ACHN cell lines. Our results are also in agreement with recent studies, showing that Cis-platinum induced apoptosis in A549 (human lung carcinoma ); HEP2 (human larynx epidermoid carcinoma); HT-29 (human colon adenocarcinoma) and MIA (human pancreas carcinoma) [35]; CP30 and A2780 (human ovarian cancer) ]36[; NT2 and NCCIT (testicular carcinoma) [30].

However, in the current study, it can be suggested that the probable Cis-platinum and TQ mechanism induce apoptosis is the under expression of $\mathrm{Bcl} 2$, over-expression of proapoptotic Bax protein, increased release of cytochrome $\mathrm{C}$ into cytosol, which induced activation of caspases 3 [24, $28,36]$, However, determination of the accurate mechanism requires further investigation.

The data indicated that TQ as an active component of $\mathrm{N}$. sativa had higher cytotoxicity in comparison with total extract of N. sativa and its fractions on GP-293 cell line, as reported in previous studies [17]. In regard with our results, a study indicated that there were certain compounds with positive synergistic effects and higher efficacy in the whole plant structure. Moreover, separating certain components of a plant as a medicinal material resulted in decreased therapeutic effects and enhanced related complications [37].

Finally, it can be suggested that total extract of N. sativa and some of its fractions had more beneficial effects on cancer treatment in comparison with a specific component such as TQ $[17,38]$. Interestingly, based on our results, Cis-platinum was more promising in reducing cell viability and inducing apoptosis in ACHN cell lines compared to GP-293 cell lines. On the other hand, it was indicated that GP-293 cell lines had higher sensitivity to TQ, as compared with ACHN cell lines.

Based on previous studies [17, 18], which compared the effect of Cis-platinum, TQ and total extract of N. sativa and its fractions on ACHN, GP-293 and L929 cell lines, it was shown that total extract of N. sativa and Cis-platinum more selectively caused cytotoxicity in ACHN cell lines. In addition, total extract of N. sativa in comparison with Cis-platinum was observed to have lower cytotoxicity effects GP293 cell lines.

\section{Conclusion}

Our findings demonstrated that TQ and Cis-platinum had cytotoxic and apoptotic effects on both the cell lines, how- ever, GP-293 cell lines were more sensitive to TQ. In addition, Cis- platinum was more effective on ACHN cell line than GP-293 cell lines.

\section{Acknowledgments}

This study was part of an MSc thesis and financially supported by Mashhad University of Medical Sciences.

\section{Conflicts of interest}

There are no conflicts of interest. 


\section{References}

1. Cohen HT, McGovern FJ. Renal-cell carcinoma. New England Journal of Medicine. 2005;353(23):2477-90.

2. Cancer Genome Atlas Research N. Comprehensive molecular characterization of clear cell renal cell carcinoma. Nature. 2013;499(7456):43-9.

3. Motzer RJ, Nanus DM, Russo P, Berg WJ. Renal cell carcinoma. Current problems in cancer. 1997;21(4):185232.

4. Murai M, Oya M. Renal cell carcinoma: etiology, incidence and epidemiology. Current opinion in urology. 2004;14(4):229-33.

5. Madias NE, Harrington JT. Platinum nephrotoxicity. The American journal of medicine. 1978;65(2):307-14.

6. Ali BH, Blunden G. Pharmacological and toxicological properties of Nigella sativa. Phytotherapy Research. 2003;17(4):299-305.

7. Boskabady MH, Mohsenpoor N, Takaloo L. Antiasthmatic effect of Nigella sativa in airways of asthmatic patients. Phytomedicine. 2010;17(10):707-13.

8. Mohebbati R, Abbsnezhad A, Khajavi Rad A, Mousavi SM, Haghshenas M. Effect of hydroalcholic extract of Nigella sativa on doxorubicin-induced functional damage of kidney in rats. The Horizon of Medical Sciences. 2016;22(1):13-20.

9. Kaleem M, Kirmani D, Asif M, Ahmed Q, Bano B. Biochemical effects of Nigella sativa L seeds in diabetic rats. 2006.

10. Chehl N, Chipitsyna G, Gong Q, Yeo CJ, Arafat HA. Anti-inflammatory effects of the Nigella sativa seed extract, thymoquinone, in pancreatic cancer cells. HPB. 2009;11(5):373-81.

11. Woo CC, Kumar AP, Sethi G, Tan KHB. Thymoquinone: potential cure for inflammatory disorders and cancer. Biochemical pharmacology. 2012;83(4):443-51.

12. Ragheb A, Attia A, Eldin WS, Elbarbry F, Gazarin S, Shoker A. The protective effect of thymoquinone, an anti-oxidant and anti-inflammatory agent, against renal injury: a review. Saudi Journal of Kidney Diseases and Transplantation. 2009;20(5):741.

13. Forouzanfar F, Bazzaz BSF, Hosseinzadeh H. Black cumin (Nigella sativa) and its constituent (thymoquinone): A review on antimicrobial effects. Iranian journal of basic medical sciences. 2014;17(12):929.

14. Das S, Dey KK, Dey G, Pal I, Majumder A, MaitiChoudhury S, et al. Antineoplastic and apoptotic potential of traditional medicines thymoquinone and diosgenin in squamous cell carcinoma. PLoS One. 2012;7(10):e46641.

15. Rooney S, Ryan MF. Effects of alpha-hederin and thymoquinone, constituents of Nigella sativa, on human cancer cell lines. Anticancer research. 2005;25(3B):2199204.

16. Shoieb AM, Elgayyar M, Dudrick PS, Bell JL, Tithof PK. In vitro inhibition of growth and induction of apoptosis in cancer cell lines by thymoquinone. International journal of oncology. 2003;22(1):107-13.

17. Shahraki S, Khajavirad A, Shafei MN, Mahmoudi M, Tabasi NS. Effect of total hydroalcholic extract of Nigella sativa and its n-hexane and ethyl acetate fractions on ACHN and GP-293 cell lines. Journal of traditional and complementary medicine. 2016;6(1):89-96.

18. Tabasi N, Mahmoudi M, Rastin M, Sadeghnia HR, HosseinPour Mashhadi M, Zamani Taghizade Rabe S, et al. Cytotoxic and apoptogenic properties of Nigella sativa and thymoquinone, its constituent, in human renal cell carcinoma are comparable with cisplatin. Food and agricultural immunology. 2015;26(1):138-56.

19. Ambrose M, Ryan A, Sullivan GCO, Dunne C, Barry OP. Induction of apoptosis in renal cell carcinoma by reactive oxygen species: Involvement of extracellular signal-regulated kinase $1 / 2$, p38, cyclooxygenase-2 down-regulation, and translocation of apoptosis-inducing factor. MOLECULAR PHARMACOLOGY. 2006;69(6):1879-90.

20. Khan A, Chen H, Tania M, Zhang D. Anticancer Activities of Nigella sativa (Black Cumin). African Journal of Traditional, Complementary and Alternative Medicines. 2011;8(5S).

21. Yi T, Cho SG, Yi Z, Pang X, Rodriguez M, Wang Y, et al. Thymoquinone inhibits tumor angiogenesis and tumor growth through suppressing AKT and extracellular signal-regulated kinase signaling pathways. Mol Cancer Ther. 2008;7(7):1789-96. Epub 2008/07/23.

22. Shafi G, Munshi A, Hasan TN, Alshatwi AA, Jyothy A, Lei KYD. Induction of apoptosis in HeLa cells by chloroform fraction of seed extracts of Nigella sativa. BioMed Central. 2009;9(29):2867-74.

23. Yazan LS. Cytotoxicity of thymoquinone (TQ) from Nigella sativa towards human cervical carcinoma cells (HeLa). Journal of Pharmacy Research. 2009;2(4).

24. Gurung RL, Lim SN, Khaw AK, Soon JFF, Shenoy K, Ali SM, et al. Thymoquinone induces telomere shortening, DNA damage and apoptosis in human glioblastoma cells. PloS one. 2010;5(8):e12124.

25. Gamarra-Luques CD, Goyeneche AA, Hapon MB, Telleria CM. Mifepristone prevents repopulation of ovarian cancer cells escaping cisplatin-paclitaxel therapy. BMC cancer. 2012;12(1):200.

26. Jafri SH, Glass J, Shi R, Zhang S, Prince M, Hancock HK. Thymoquinone and cisplatin as a therapeutic combination in lung cancer: In vitro and in vivo. Journal of Experimental \& Clinical Cancer Research. 2010;29(87):543-9.

27. Arafa el SA, Zhu Q, Shah ZI, Wani G, Barakat BM, Racoma I, et al. Thymoquinone up-regulates PTEN expression and induces apoptosis in doxorubicin-resistant human breast cancer cells. Mutat Res. 2011;706(12):28-35. Epub 2010/11/03.

28. Shoieb AM, Elgayyar M, Dudrick PS, Bell J, Patricia TK. In vitro inhibition of growth and induction of apoptosis in cancer cell lines by thymoquinone. International journal of oncology. 2003;10(22):107-13.

29. Venkatraman M, Anto RJ, Nair A, Varghese M, Karunagaran D. Biological and chemical inhibitors of NF- $x \mathrm{~B}$ sensitize SiHa cells to cisplatin囚induced apoptosis. Molecular carcinogenesis. 2005;44(1):51-9.

30. Burger H, Nooter K, Boersma A, Kortland C, Stoter G. Expression of p53, Bcl-2 and Bax in cisplatin-induced apoptosis in testicular germ cell tumour cell lines. British journal of cancer. 1998;77(10):1562.

31. ZHANG RG, ZHANG RP, Xing Wang W, Hong X. Effects of cisplatin on telomerase activity and telomere length 
in BEL-7404 human hepatoma cells. Cell research. 2002;12(1):55-62.

32. El-Mahdy MA, Zhu Q, Wang QE, Wani G, Wani AA. Thymoquinone induces apoptosis through activation of caspase-8 and mitochondrial events in p53-null myeloblastic leukemia HL-60 cells. International journal of cancer. 2005;117(3):409-17.

33. Gali-Muhtasib HU, Kheir WGA, Kheir LA, Darwiche N, Crooks PA. Molecular pathway for thymoquinone-induced cell-cycle arrest and apoptosis in neoplastic keratinocytes. Anti-cancer drugs. 2004;15(4):389-99.

34. Koka PS, Mondal D, Schultz M, Abdel-Mageed AB, Agrawal KC. Studies on molecular mechanisms of growth inhibitory effects of thymoquinone against prostate cancer cells: role of reactive oxygen species. Experimental Biology and Medicine. 2010;235(6):75160.

35. Rooney S, Ryan MF. Effects of alpha-hederin and thymoquinone, constituents of Nigella sativa, on human cancer cell lines. Anticancer Res. 2005;25(3B):2199204. Epub 2005/09/15.

36. Henkels KM, Turchi JJ. Cisplatin-induced apoptosis proceeds by caspase-3-dependent and - independent pathways in cisplatin-resistant and -sensitive human ovarian cancer cell lines. Cancer Res. 1999;59(13):307783. Epub 1999/07/09.

37. Mojab F. Antimalarial natural products: a review. Avicenna Journal of Phytomedicine. 2012;2(2):52-62.

38. Shahraki S, Khajavirad A, Mahmoudi M, Tabasi N, Havakhah S, Hosinian S, et al. Effect of aqueous fraction of Nigella sativa on percentage of live cells in human renal carcinoma cell line (ACHN) and normal human renal epithelial cells (GP-293). Journal of North Khorasan University of Medical Sciences. 2013;5(3):585-91. 